\title{
Status Research of Working Class Securities Investment in Xining Qinghai Province
}

\author{
Yunlei Huo ${ }^{1, a}$ \\ ${ }^{1}$ Jilin Business and Technology College, Changchun, Jinlin, China, 130507 \\ ${ }^{a}$ email
}

Keywords: Jilin, Working Class, Investment Securities

\begin{abstract}
With the development of the national economy in Xining Qinghai region, working class income in Jilin province has been tremendous growing, they have the economic conditions of investment securities and real needs. Working class research on specific issues of investment securities has greater significance for the stable development of the securities market value and working class assets.
\end{abstract}

\section{Introduction}

Xining in Qinghai Province in the national economy, the rapid development of the region, the income of wage earners has also increased. According to statistics, in 2012 income of urban residents' in Jilin region grew by more than $15 \%$, further increasing the per capita disposable income of wage earners pay personal income tax accounted for more than $50 \%$ of the total personal income tax. These data suggest that the working class area in Jilin income increasing, its economic strength has been further strengthened, the previous "low-income wage earners are" concept is increasingly diluted.

With the increased surplus of income over expenditure, working class risk prevention capacity in Jilin province also enhanced synchronization and they already have investment securities economic conditions.

\section{The Problems of Working class Investment Securities in Xining Qinghai}

Among the working class of Jilin, the two main sources are operating revenue and financial revenue. Due to the current financial concepts more traditional working class majority, coupled with China's overall financial condition is not mature enough, financial income is very limited. In contrast, income from work in the working class economic sources still account for a large proportion of them is an important basis for financial management and it is realistic conditions of wage earners making investment securities to be considered. In 2012 by the United Nations 72 countries working class income, the average monthly wage of \$1518.48, equivalent to approximately RMB 9327 RMB; China's per capita monthly income of \$ 702.31, equivalent to approximately RMB 4134 $\mathrm{RMB}$, a difference of nearly half of the Chinese show per capita income less than half of the working class world. The authenticity of the results to be verified, but the income of wage earners the Jilin area affected by various factors really low. 2012 Jilin area of wage earners per capita income is only $3024 \mathrm{RMB}$, with the national average there is a gap $4134 \mathrm{RMB}$. Another factor working class area of Jilin income is wages too slow. According to the survey in 2003 - between 2012, salaries rose faster in the social middle class wage earners slowest.

"Since 2006, wages have never been up." This is the Jilin respondents Zhang Ying words. Zhang Ying, a large state-owned enterprise in Jilin City for 10 years, from 2003 - In 2006, the wage from 4,000 RMB/month rose to 6,000 RMB/month, but from 2006-2012, wages only 6,000 RMB/month rose $8000 \mathrm{RMB} / \mathrm{month}$. This situation is similar to Zhang Ying in Jilin region is relatively common, working class wages have gone up speed is too small is an indisputable fact. With the rise in prices, fixed salaries for necessary living expenses will increase in the proportion of funds for investment in securities will be reduced.

Currently working class area in Jilin most in 20 years of age to 60 years of age, in which the 
proportion of 25 years old to 50 years of age the biggest crowd, that is, the proportion of the population in the development of the family and the mature region of the two largest stages of life. Their future trend of social development has many worries long and short term, that their job prospects, the future education of children, parents pension nail in the coffin, security and other aspects of a healthy body there is more uncertainty. Such living conditions to determine their liquidity funds, monetary liquidity and so have many requirements, so the basic objective of the investment is relatively consistent, is to get regular wages income to meet daily needs or for the future protection.

These two stages of working class life is in a strong period of life, either their own age or understanding of the characteristics of the society so that they are in working class on basic survival needs have to meet under the premise of focusing more on energy achieve to improve the quality of life, improve the consumer goods related projects. They not only for travel, fitness, beauty, entertainment and universal pursuit, but also for education, real estate, cars, maintaining interpersonal expenditures are quite different, so make the limited economic income for achieving greater investment strategy combination aspects of utility levels also have different requirements.

In the vast majority of working class area in Jilin are not professional financial professional graduates, their professional variety, knowledge of the stock market is limited, not to mention some professional analysis, the investment approach. They diversified investment rate of return, the bond price changes, as well as a certain lack of investment directions discrimination ability. Some wage earners also like to see some investment finance books for investment, but the investment banking market all kinds of books voluminous, truly valuable, practical and easy-almost no feasible method, the actual situation is not the same for everyone, will be scripted kill people, but walked into a misunderstanding.

\section{The Problems Faced By Working Class Area of Jilin Settlement Proposals}

Although the same working class area of Jilin, but their income levels are still quite different.

Low-income people should generally use more traditional and conservative approach to investing in securities, such as purchase of treasury bills.

Middle-income wage earners are generally opposed to the traditional concept of investment, financial management concepts family demands absolute sound. So they should do a monthly spending plan, in addition to the normal expenses, the remaining part can be divided into several parts to focus on finance and investment securities investment products, avoid broad and full, frequent trading. For the risky stock market, taking into account the working class risk-bearing capacity is weak, the expertise is relatively scarce and the focus cannot be considered. Insurance, investment funds and bonds and other products are still the main choice of the income of wage earners.

As for the securities investment strategy in high-income wage earners, most of the funds can be considered offensive for the investment, the greater the play "money begets money" function. But taking into account the risk factors, "attack" of the funds can be divided into "stable attack" and "storm" in two parts. For the stable part of the attack, there is a certain concept of finance and investment people can choose to buy some small degree of market volatility is expected to return more robust securities products, such as hybrid funds, large blue chips, aiming annual rate of return of $5 \%-10 \%$ level; the storm was part of certain high-risk high-yield Securities portfolio. It can be considered under the guidance of a professional financial planner, part of the money into various types of higher expected rate of return on stocks.

Investment in securities, both have a grasp of individual stocks and bonds, funds market, but also have a portfolio of ideas to moderate diversification to reduce risk. Overall, in the development of securities investment strategy for the working class, to pay more attention to their different needs for different purpose and price elasticity of demand and risk types of products, thus protecting their existing assets and the standard of living is not affected case, to achieve enhance the future value of assets and quality.

Determination of the type of risk appetite depends on the investor's age, income, gender, 
experience and personality and other specific factors. In Jilin area, younger wage earners do not fear failure, so much risk tends to investors; with increasing age, the risk gradually showed neutral attitude and even aversion. Overall, in the Jilin area most people belong to the risk-averse and risk neutral, securities investment risk tolerance overall quite limited.

For the risk neutral wage earners can take in high, medium and low-risk type of investment vehicles in different settings in different proportions in order to achieve the effect of avoiding disadvantages, of course, can put at risk the funds are mainly medium bond and hybrid funds, so you can focus on in-depth analysis of the species are concentrated, in order to gain higher returns.

Risk-averse investors on the one hand can be taken in Jilin buy Treasuries, bond funds, money funds invest mainly simple way, it can also, according to various reports and annual appraisal results, choose a better society and economic securities companies, fund companies, banks and other financial institutions, investments aggregating securities. Relatively speaking, money market funds compared with other low-risk financial products, at yields equal, in terms of liquidity and investment barriers have obvious advantages, to meet investors prefer low-risk financial products for capital high liquidity and stability requirements for comprehensive income, it is proposed that part of the population as a preferred investment vehicle. Of course, with the Jilin area securities investment philosophy of in-depth development of the securities industry, index funds, hybrid funds can be the low-risk securities investment products.

For risk-based wage trend investors can increase the proportion of securities investment in new varieties, new products, since it is often in the back also implies high risk high-yield.

\section{References}

[1] Wu Gebin. How do the family finances [J]. Economic Research Guide, 2010 (16).

[2] Liu Xiaolin. Wage earners benefit over a thousand one hundred million [J]. People's Daily Overseas Edition, 2011. (03).

[3] Ma Jie. Negative interest rate era working class finance and investment policy to explore[J]. Accounting communication, 2012 (20)

[4] ViViana Fernandez. Risk management under extreme events[J]. International Review of Financial Analysis, 2005

[5] Simone Manganelli, Robert F. Engle. Value-at-Risk models in finance [J]. ECB Working Paper, 2001 